$\begin{array}{lll}\text { A shot in the arm } & \begin{array}{l}\text { Sanity clause } \\ \text { Experts seek fresh } \\ \text { approach to flu } \\ \text { vaccines }\end{array} \\ \text { p742 } & \begin{array}{l}\text { Cloned cattle show } \\ \text { resistance to mad } \\ \text { cow disease } \\ \text { p743 }\end{array} & \begin{array}{l}\text { Meet the family } \\ \text { Coral study hints } \\ \text { at lengthy genetic } \\ \text { lineage } \\ \text { p744 }\end{array}\end{array}$

\title{
Accusations of bias prompt NIH review of ethical guidelines
}

\section{Jonathan Knight, San Francisco}

The US National Institutes of Health $(\mathrm{NIH})$ is to reassess its ethics rules following allegations that consulting fees paid to some of its top scientists have biased decisions in clinical research.

The charges, levelled by the Los Angeles Times on 7 December, centre on consulting fees paid to a number of the agency's top scientists by private drug firms. The paper alleged that such deals had influenced research decisions involving the companies' products.

It also suggested that the problem runs deep and is hidden from public view by rules that allow most NIH scientists to keep their consulting deals confidential.

The office of NIH director Elias Zerhouni issued a statement on 10 December to say that the allegations are being investigated but that all employees are believed to have followed government ethics rules. Nevertheless, it added: "We will need to consider changes after a thoughtful analysis of the issue."

The House Committee on Energy and

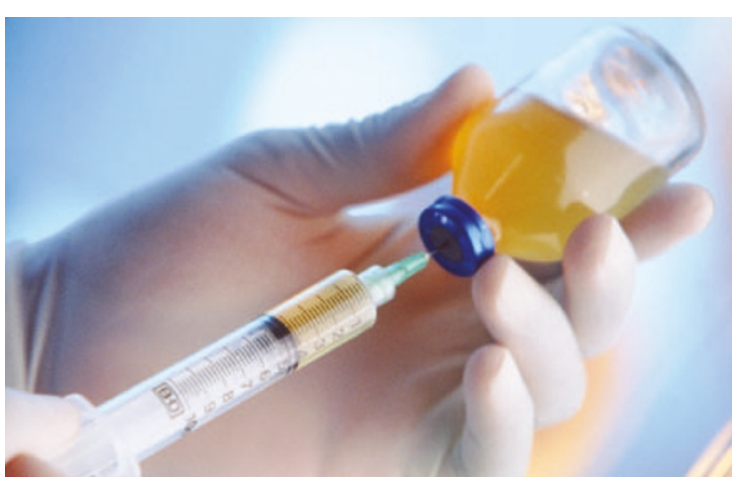

Are consultancy fees exerting undue influence on clinical trials?

in an attempt to make the NIH more attractive to top researchers. Under the new rules, scientists continued to be barred from consulting if they were also directly involved in a company's dealings with the NIH, and all deals were subject to approval by ethics staff.

But according to the Los Angeles Times, these guidelines have not prevented conflicts of interest - and in some instances may have biased decisions on clinical research. Cecil Fox, a private research consultant in Little Rock, Arkansas, says that the paper's article is right on target. Fox was a sciCommerce, which oversees the NIH, has demanded complete records of all consulting deals made by in-house NIH scientists since 1999. The agency has offered its full cooperation with the investigation.

The NIH campus in Bethesda, Maryland, is the world's largest biomedical research centre. But until 1995, scientists there faced strict limits on their consulting activities. These rules were revoked by then director Harold Varmus

\section{Scientists attack industrial influence}

\section{Jonathan Knight, San Francisco}

Four scientists who feel that their work has been suppressed by the biotechnology industry issued a call for greater scientific freedom at a rally on 10 December at the University of California, Berkeley.

Nearly 500 people turned up to hear the researchers describe the obstacles they claim to have faced in disseminating research findings that questioned the safety of pesticides and genetically engineered crops.

"I want to make this the beginning of something," said Ignacio Chapela, the Berkeley ecologist who organized the event. Chapela claims that he was denied tenure at Berkeley last month because of his outspoken stance against corporate financing of public research (see Nature 426, 591; 2003).

At the rally, Berkeley amphibian

\section{biologist Tyrone Hayes gave a detailed} account of what he called industry attempts to suppress and discredit his work on atrazine, the most widely applied herbicide in the United States.

Joining the rally on an Internet video link was John Losey, an entomologist at Cornell University in Ithaca, New York, who in 1999 found that pollen from insecticideproducing maize is toxic to monarch butterfly larvae. Losey said he had been asked by industry representatives not to publish his findings.

One sceptic asked if the panellists were really victims of suppression, when their findings had attracted so much publicity. Chapela responded that for each panel member there were many others whose careers were ended by industry pressure. "We are the survivors," he said. entist at the National Institute for Allergy and Infectious Diseases from 1973 to 1991, and consulted for many labs at the Bethesda campus until last year. He says that private deals with industry have seriously compromised the independence of many NIH researchers.

Colleagues of the researchers named in the Los Angeles Times article have been quick to spring to their defence. One, who spoke on the condition of anonymity, said that the ethics charges were completely overblown. "I know the people and they are people of the highest integrity," he said.

But the high degree of confidentiality surrounding consulting deals at the NIH is disturbing even some of the agency's defenders. The 1989 Ethics Reform Act requires prominent or highly paid government employees to file public disclosures of outside income. Other employees, meanwhile, file confidential reports that can be reviewed by Congress, but that are not available to the public.

With more than $94 \%$ of its high-earning employees falling into the bracket, the NIH has one of the highest percentages of confidential filers in the government. In part, this is because the agency has widened its pay bands in recent years, assigning highly paid staff to grades that allow confidential filing.

These wider pay brackets were the only way the NIH could increase the salaries of high-level scientists that it didn't want to lose, says Varmus. But he adds there should be greater public transparency from the NIH: "I think that should be reviewed at this point." 